\title{
BABESIA UGWIDIENSIS, A neW Species of aVian Piroplasm from Phalacrocoracidae in SoUth Africa
}

\author{
PEIRCE M.A.* \& PARSONS N.J.**
}

\section{Summary:}

A new species of haematozoa, Babesia ugwidiensis sp. nov. from a cormorant is described. This is the first species of piroplasm to be recorded from the Phalacrocoracidae and the relationship of this parasite to other Babesia spp. from marine hosts is discussed.

KEY WORDS: Babesia, piroplasm, cormorant, marine bird, tick vector.

\section{INTRODUCTION}

$\mathrm{N}$ ew species of haematozoa were recently described from Phalacrocoracidae and Stercorariidae in South Africa (Parsons et al., 2010). As part of the on-going survey of the health of sick and injured marine and coastal birds presented to the Southern African Foundation for the Conservation of Coastal Birds (SANCCOB) for examination and release when possible, new and hitherto undescribed blood parasites have been observed as a result of a range of veterinary investigations to which such birds are subjected, including screening for the presence of blood parasites. A new species of avian piroplasm has been found in several species of cormorants and is herein described. An appraisal of the current status of this and other avian piroplasms described since the last review (Peirce, 2000) is also discussed.

\section{MATERIALS AND METHODS}

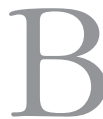
irds were bled from the medial metatarsal vein as it lies over the tarsal bone with a $23 \mathrm{G}$ or $25 \mathrm{G}$ needle (depending on the size of the bird). Blood was collected directly from the hub of

* MP International Consultancy, 6 Normandale House, Normandale, Bexhill-on-Sea, East Sussex, TN39 3NZ, UK, \& Corresponding Associate, International Reference Centre for Avian Haematozoa, Queensland Museum, PO Box 3300, South Brisbane, QLD 4101, Australia. ** Southern African Foundation for the Conservation of Coastal Birds, PO Box 11116, Bloubergrant 7443, South Africa.

Correspondence: Michael A. Peirce.

Tel.: 44 (0)1424 736402 - Fax: 44 (0)1424 736402.

E-mail: mapeirce.mpic@btinternet.com
Résumé : BABESIA UGWIDIENSIS, UNE NOUVELLE ESPĖCE DE PIROPLASME de Phalacrocoracidae en Afrique du Sud

Description d'une nouvelle espèce d'hématozoaire, Babesia ugwidiensis $n$. sp., chez des cormorans. Cette espèce est le premier piroplasme décrit des Phalacrocoracidae. La parenté de ce parasite avec les autres espèces de Babesia d'hôtes marins est discutée.

MOTS-CLÉS : Babesia, piroplasme, cormoran, oiseau de mer, tique, vecteur.

the needle into a heparinised capillary tube. A thin blood smear was made immediately, air-dried, fixed in methanol for three minutes and stained with modified Wright-Giemsa stain (Kyro-Quick ${ }^{\mathrm{TM}}$ stain set, Kyron Laboratories (pty) Ltd, Benrose, South Africa). All slides were initially screened at SANCCOB, each slide being examined for ten minutes, using a $50 \times$ oil immersion lens. A selection of slides found to contain parasites were subsequently re-examined by MA Peirce. These slides were screened under a microscope initially at $160 \times$ and $800 \times$ and then under $1,000 \times$ oil immersion magnification. All images were captured using a digital camera attached to the microscope. Morphometric measurements were obtained using a screw micrometer calibrated against a standard stage micrometer. Due to the small and delicate nature of the parasites, drawings were prepared to provide a clearer morphological picture.

Many of the birds were sampled on a weekly basis while at SANCCOB which allowed the course of infection to be followed in some instances and the parasitaemia monitored. Reference slides have been deposited in the International Reference Centre for Avian Haematozoa (IRCAH) Collection. Any ticks found on birds were carefully removed for subsequent identification.

\section{RESULTS}

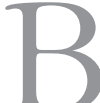
etween 2001 and 2011, a total of 851 cormorants were bled at least once. These comprised five species: 689 Cape Cormorant Phalacrocorax capensis ( $56 \%$ positive), 33 Bank Cormorant $P$. neglectus (36\% positive), 57 White-breasted Cormo- 
rant $P$. carbo ( $25 \%$ positive), 64 Crowned Cormorant P. coronatus (5\% positive) and eight Reed Cormorant P. africanus ( $13 \%$ positive). The positive birds were all infected with hitherto undescribed intraerythrocytic species of piroplasms, presumably of the genus Babesia. The level of parasitaemia in individual birds ranged from $0.1 \%$ to $16.0 \%$. In some instances the level of parasitaemia rose before falling again, ie the initial parasitaemia in one $P$. coronatus showed a level of $5.0 \%$ on 17 October 2011, which rose to $16.0 \%$ a week later. It was rare to find any ectoparasites other than lice. Only one bird, a P. capensis chick, was carrying any ticks on it (12 larvae), which were identified as the argasid Ornithodoros capensis (Carios capensis is now recognised as Ornithodoros capensis (Guglielmone et al., 2010)). Blood smears from this bird when first sampled at three weeks old were negative for parasites, but when sampled again at 4 w.o. (19 December 2011) it was positive for Babesia with a parasitaemia of $4.0 \%$. The bird was re-sampled on 26 December 2011, 03 January 2012 and 09 January 2012 when the parasitaemias were $0.5 \%, 6.0 \%$ and $0.5 \%$ respectively. There was no evidence of apparent morbidity due to the infection and the bird was not administered any treatment.

\section{TAXONOMIC REVIEW}

Family: Phalacrocoracidae (cormorants).

Parasite: Babesia ugwidiensis sp. nov. (Figs 1a-d, 2a-i) Type host: Phalacrocorax carbo (L.).

Type locality: SANCCOB, Bloubergrant, South Africa. Vector: possibly Ornithodoros capensis (Neumann, 1901) on circumstantial evidence.

Etymology: named after the Xhosa name for cormorant. Other cormorant species infected with morphologically identical piroplasms: $P$. capensis, $P$. coronatus, $P$. neglectus and $P$. africanus. These presumably occur
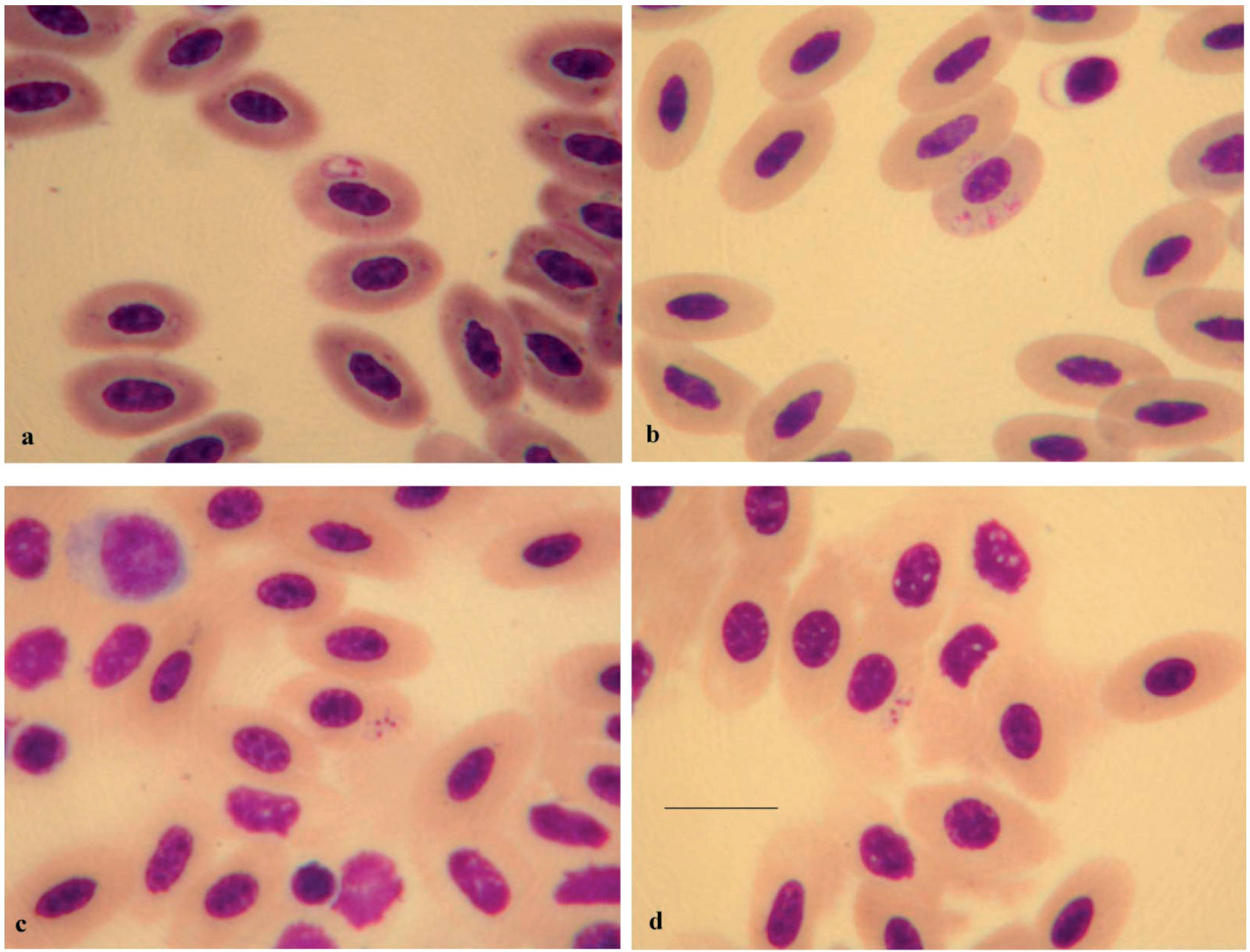

Fig. 1. - Babesia ugwidiensis sp. nov. from Phalacrocorax carbo.

(a) elongate schizont precursor; (b) three spherical schizont precursors in same cell; (c-d) dividing tetrad schizonts showing proximal position of nucleus within the merozoites. Merozoites are just beginning to separate. Scale bar $=10 \mu \mathrm{m}$. 
throughout Africa in other species of Phalacrocoracidae and probably over the geographic range of the family.

\section{DESCRIPTION}

The smallest parasites seen are ring forms comprising a compact mass of chromatin with a pale central cytoplasm measuring $0.5 \mu \mathrm{m}$ (Fig. 2a). These grow in size (Fig. 2b-c) and gradually show an increase in the chromatin, which begins to divide. These forms either retain their generally round shape (Figs 1b, 2e) and measure $3.11 \pm 0.34 \mu \mathrm{m}$ (range 2.43-3.9 $\mu \mathrm{m})(n=20)$ or become oval to elongate (Figs 1a, 2d) measuring $4.28 \pm 0.46 \times 2.5 \pm 0.42 \mu \mathrm{m}$ (range 3.6-5.1 $\times 1.62$ $3.24 \mu \mathrm{m})(n=13)$. These schizont precursors which may sometimes appear as amoeboid forms (Fig. 2f) develop into tetrad schizonts (Figs 1c-d, 2g-h) measuring $5.65 \pm 0.41 \times 2.83 \pm 0.26 \mu \mathrm{m}$ (range 5.04-6.21 $\times$
2.4-3.36 $\mu \mathrm{m})(n=12)$. The nucleus in the merozoites is proximal and typical cruciform "Maltese-cross" schizont forms are rarely seen. The merozoites, which are elongate and generally pyriform eventually separate (Fig. 2i) and measure $2.62 \pm 0.14 \times 1.34 \pm 0.18 \mu \mu \mathrm{m}$ (range $2.22-2.91 \times 0.99-1.71 \mu \mathrm{m})(n=30)$. After separation the merozoites gradually round up. Where multiple invasion of erythrocytes is seen, this appears to be from the post-schizont merozoites growing within the same host cell, rather than from invasion by other parasites. There is no displacement of the host cell nucleus and no direct evidence of pathogenicity.

\section{HAPANTOTYPE}

IRCAH: G 465493 from P. carbo coll. Parsons, 5 January 2009, SANCCOB, Bloubergrant, South Africa; deposited in IRCAH Collection, Queensland Museum, Brisbane, Australia.

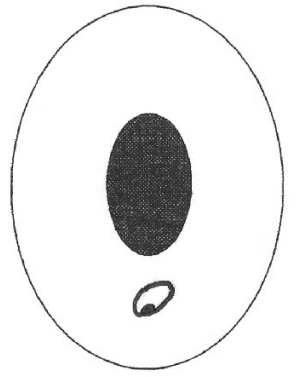

a

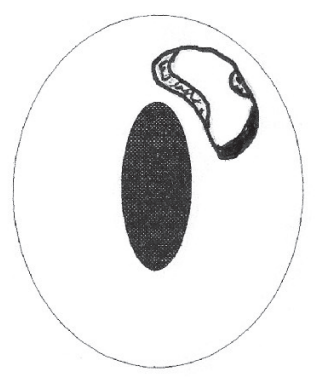

d

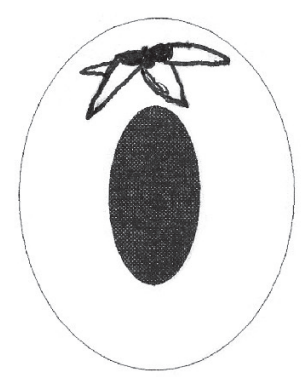

g

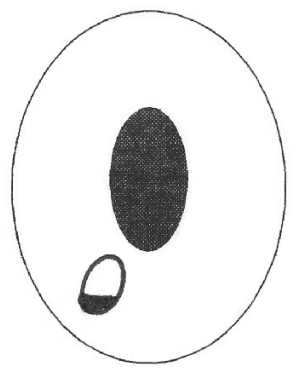

b

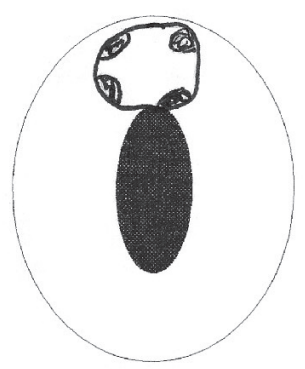

e

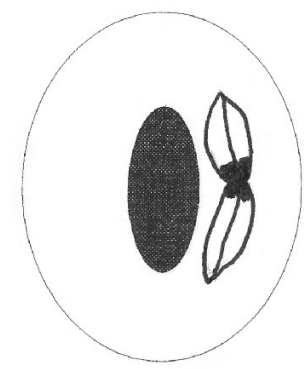

h

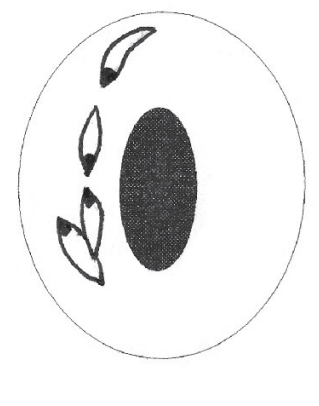

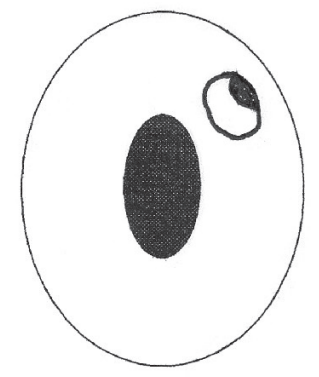

C

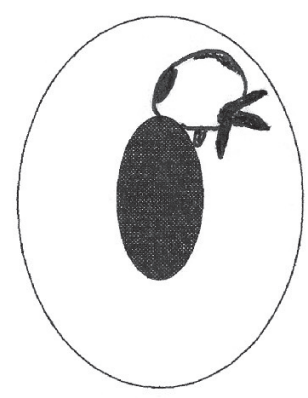

f

Fig. 2. - Drawings illustrating the development of Babesia ugwidiensis sp. nov. in Phalacrocorax carbo.

(a) early ring form; (b-c) trophozoites; (d) elongate schizont precursor; (e) spherical schizont precursor showing four chromatin masses; (f) developing amoeboid schizont; (g-h) mature tetrad schizonts; (i) merozoites separated from schizont. Scale bar $=4 \mu \mathrm{m}$. 


\section{PARAHAPANTOTYPES}

IRCAH: G 465494 from P. carbo coll. Parsons, 19 January 2009; IRCAH: G 465495 from P. capensis coll. Parsons, 5 January 2009; IRCAH: G 465496 from $P$. capensis coll. Parsons, 26 January 2009; IRCAH: G 465497 from P. capensis coll. Parsons, 18 July 2011. All from SANCCOB, Bloubergrant, South Africa; deposited in IRCAH Collection, Queensland Museum, Brisbane, Australia.

\section{COMMENTS}

B. ugwidiensis sp. nov. is readily distinguished from other Babesia spp. of marine birds by the proximal location of the nucleus within the merozoite. It would appear, like most other avian piroplasms, this species is host-specific to the Phalacrocoracidae.

\section{DISCUSSION}

$\mathrm{I}$ $\mathrm{n}$ a review of avian piroplasms of the genus Babesia, Peirce (2000) accepted 13 species as being valid. Since then two additional species have been described, Babesia kiwiensis from the kiwi Apteryx australis mantelli (Peirce et al., 2003) and B. uriae from common murres Uria aalge (Yabsley et al., 2009). The description of B. ugwidiensis presented here brings the total number of species to 16. $B$. ugwidiensis is a parasite occurring very commonly in $P$. carbo and presumably other cormorants where quite a high prevalence is seen in several species, especially in Cape cormorants. Although some species of avian Babesia do cause some degree of pathogenicity and morbidity particularly B. shortti in falcons, B. peircei in penguins and B. kiwiensis in kiwi (Peirce, 2000; Peirce et al., 2003), there is no evidence that B. ugwidiensis has any direct observable morbidity in cormorants. However, a high proportion of cormorants received at SANCCOB are emaciated, often due to high worm burdens, and in those cases where B. ugwidiensis may also be present as a concomitant infection, it might contribute to the overall morbidity in some birds.

Molecular characterisation of B. kiwiensis, B. poelea and $B$. uriae confirms that avian piroplasms are more closely related to mammalian Babesia than to Theileria (Yabsley et al., 2006; Yabsley et al., 2009; Jefferies et al., 2008). It is hoped that an on-going molecular study (Yabsley, pers. com.) will confirm also whether $B$. poelea is a valid species or a synonym of $B$. peirce $i$ as suggested by Peirce (2000). B. ugwidiensis can be easily distinguished morphologically from other Babesia spp. from marine birds by the proximal position of the nucleus in merozoites which in B. peircei, B. poelea and B. uriae occur distally. Molecular studies will also have to confirm that the piroplasms found in other cormorant species than $P$. carbo also belong to B. ugwidiensis.

At present nothing is known for certain about the vector of $B$. ugwidiensis which until now has been assumed to be a species of ixodid tick, although in colonial ground-nesting species there is always the possibility that argasid ticks of the genus Ornithodoros (synonyms: Alectorobius; Carios) could be involved (Peirce, 2000). The most common species associated with sea birds is O. capensis, which Theiler (1959) recorded mainly from nests, although also from penguins and gannets by inference from colonies on the Guano Islands around the Cape. Although not recorded from cormorants in the same area, O. capensis has been recorded from the nests of $P$. carbo in Ethiopia and Tanzania (Hoogstraal et al., 1976). While Ixodes uriae is the most common ixodid tick collected from sea birds in southern African waters there appear to be no records from cormorants, gannets or penguins (Heyne, pers. com.). Since O. capensis was the only species of tick to be found on any birds at SANCCOB, from one $P$. capensis chick, which subsequently developed B. ugwidiensis, there is a strong possibility that this tick may be the vector, although further study is required to demonstrate this conclusively. Additionally, since the ticks recovered were all larvae, this suggests that trans-ovarial transmission occurs as it does with most species of Babesia transmitted by ixodid ticks, as well as trans-stadial. Another factor in favour of $O$. capensis being the vector is provided by the rapid feeding of all stages, larvae, nymphs and adults, all of which feed within an hour or two when conditions are right, due to the anatomy of the mouth parts. Conversely, I. uriae takes considerably longer with larvae and nymphs being attached on the host for six-12 days and females about eight days (Frenot et al., 2001). Thus it is surprising that I. uriae have not been found on any of the birds examined at SANCCOB. There is ongoing work to identify all species of ectoparasites occurring on the different bird species admitted to SANCCOB.

It is highly probable that ground-nesting marine birds (penguins, gannets and cormorants) which share the same or contiguous nesting areas are sharing the same species of tick, which may be transmitting more than one species of avian Babesia. On the available evidence it does appear that argasid ticks may be more important in the transmission of avian Babesia spp. in marine birds rather than ixodid ticks.

\section{ACKNOWLEDGEMENTS}

VTe are grateful to Michael Yabsley, University of Georgia, USA for information on his molecular 
studies, and to Heloise Heyne curator of the South African National Tick Collection at Onderstepoort for providing data on tick species recorded from sea birds and for identifying the ticks recovered from the Cape cormorant chick. The authors thank the many staff and volunteers at SANCCOB. SANCCOB is supported by a wide range of donors, including the International Fund for Animal Welfare (IFAW), Hans Hoheisen Charitable Trust and the National Lottery Distribution Fund (NLDTF). This research is supported by the Sea Research Foundation (Mystic Aquarium) and the Georgia Aquarium. NJP also acknowledges support from the National Research Foundation (SEACHANGE programme), Earthwatch Institute and the University of Cape Town Research Committee.

\section{REFERENCES}

Frenot Y., de Oliveira E., Gauthier-Clerc M., Deunff J., Bellido A. \& Vernon P. Life cycle of the tick Ixodes uriae in penguin colonies: relationships with host breeding activity. International Journal for Parasitology, 2001, 31, 1040-1047.

Guglielmone A.A., Robbins R.G., Apanaskevich D.A., Petney T.N., Estrada-Pena A., Horak I.G., Shao R. \& Barker S.C. The Argasidae, Ixodidae and Nuttalliellidae (Acari: Ixodida) of the world: a list of valid species names. Zootaxa, 2010, 2528, 1-28.

Hoogstraal H., Kaiser M.N. \& Easton E.R. Ornithodoros (Alectorobius) capensis Neumann (Ixodoidea: Argasidae) parasitizing a human and birds nesting on islands in East African lakes. Journal of Medical Entomology, 1976, 12, 703-704.

JefFeries R., Down J., McInnes L., Ryan U., Robertson H., JAKOB-HOFF R. \& IRWIN P. Molecular characterization of Babesia kiwiensis from the brown kiwi (Apteryx mantelli). Journal of Parasitology, 2008, 94, 557-560.

Parsons N.J., Peirce M.A. \& Strauss V. New species of haematozoa in Phalacrocoracidae and Stercorariidae in South Africa. Ostrich, 2010, 81, 103-108.

PeIRCE M.A. A taxonomic review of avian piroplasms of the genus Babesia Starcovici, 1893 (Apicomplexa: Piroplasmorida: Babesiidae). Journal of Natural History, 2000, 34, 317-332.

Peirce M.A., Jakob-Hoff R.M. \& Twentyman C. New species of haematozoa from Apterygidae in New Zealand. Journal of Natural History, 2003, 37, 1797-1804.

Theiler G. African ticks and birds. Ostrich, 1959, Supplement 3, 353-378.

Yabsley M.J., Greiner E., Tseng F.S., Garner M.M., NOrdHausen R.W., Ziccardill M.H., Borjesson D.L. \& ZabolotZKY S. Description of novel Babesia species and associated lesions from common murres (Uria aalge) from California. Journal of Parasitology, 2009, 95, 1183-1188.
YABsley M.J., Work T.M. \& RAmeYer R.A. Molecular phylogeny of Babesia poelea from brown boobies (Sula leucogaster) from Johnston Atoll, Central Pacific. Journal of Parasitology, 2006, 92, 423-425.

Received on June $11^{\text {th }}, 2012$ Accepted on July $25^{\text {th }}, 2012$ 